\title{
A CORRELATIONAL STUDY BETWEEN VOCABULARY MASTERY AND READING COMPREHENSION AT ECONOMIC FACULTY OF ALKHAIRAAT UNIVERSITY
}

\begin{abstract}
AFIFAH
Abstact:

This rerch is a comdational study with two vanables - vanableX standingfor vocabulary mastery and vaniable $Y$ standing for reading compthension. There were three rearch questions (1) What is thelede of comdation between variableX and variableY?; (2) How significant is the contribation that can begiven by vaniableX toward variableY?; and (3) Is there positivecomdation between variableX and variableY? Thesampleof this reserch vas fifty sudents of the first semester at Economic Faailty of Alkhairaat Univesity. The instruments weretests and questionnaire Through tests, it was found that: (1) The led of comdation between variableX and variable $Y$ was strong (2) The significant contribution given by variable $\mathrm{X}$ toward vaniable $\mathrm{Y}$ was $52.8 \%$, meaning variable $\mathrm{X}$ gave much contribution to variable Y; and (3) There was positive condation between variable $X$ and variableY sincethevalue of $r$-counted (0.727) was higher than thevalue of $r$-table $(0.279)$. Through questiomaire, $46 \%$ respondants agreed that voabulary took a rdein hipingthemto comprenend Engish texts, mening the more vocabulary they have, the better they are in comprenendingEngish texts
\end{abstract}

Key Words: correlational study, vocabulary mastery, reading comprehension 


\section{Introduction}

English has already been one of the compulsory subjects that must be taught to the first semester students in all collages in Indonesia no matter what field of study the students focus on. However, teaching ESP (English for Specific Purposes) is somewhat different from teaching EGP (English for General Purposes). ESP students learn English to support their major. Therefore, there should be relevance between English subject and their focus of study.

The purpose of ESP itself is to enable the students to understand English literatures related to their major. Reading texts usually become the opening material in every chapter in almost all of ESP textbooks. The other language skills are developed based on the topic discussed in the reading texts as well. A problem then appears when the students cannot get the idea of the reading texts. The researcher suspected that the reason is related to the students' limitation in vocabulary mastery. This problem happened at Economic Faculty of Alkhairaat University.

It is true that the students have already been learning English since they were in Elementary School, but it does not guarantee them to be free from problems in English. Since they are ESP students, they absolutely require English for Economics. Many words related to economics are unfamiliar to them. This obstacle then becomes a problem for them to understand English texts which always appear in every chapter in every meeting.

Vocabulary plays an important role not only in supporting reading comprehension, but also in communication. Vocabulary even takes bigger part in language than grammar is. Without grammar very little can be conveyed, without vocabulary nothing can be conveyed. ${ }^{1}$ Vocabulary mastery and reading comprehension are two different matters that relate each others. Vocabulary knowledge involves knowing the meanings of words and therefore the purpose of a vocabulary test is to find out whether the learners can match each word with a synonym, a dictionary-type definition or an equivalent word in their own language. ${ }^{2}$ Since the vocabulary

${ }^{1}$ Scott Thornbury, How to Teach Vocabulary, (Edinburgh: Pearson Education Limited, 2002). p. 13.

2 John Read, Assessing Vocabulary, (Cambridge: Cambridge University Press, 2000). p. 16. 
can represent meaning, people then use vocabulary to state what they mean.

In reading comprehension, a reader communicates with a writer through written words. Reading is transfer of meaning and message from a writer to a reader. ${ }^{3}$ Since it relates very closely to meaning - which can be gained though vocabulary -, the target activity of reading is, of course, to understand. Reading without understanding cannot be called as reading. ${ }^{4}$ It is reasonable because people do activity of reading in order to find out information. However, the message of information will be blurred without understanding. Even positions understanding comprehension - as the product of reading activity. ${ }^{5}$ The product can be obtained only after completing the process. The process, in this case, refers to reading activity itself.

Reading activity is must in present era. That is why reading comprehension is included as compulsory English material in ESP for all fields of study. Why? Nowadays, many literatures, both in printed and unprinted versions, are written in English. University students are required to comprehend not only the literal meaning of every word but also the overall content of the text. ${ }^{6}$ In order to comprehend the overall content, the students should have adequate vocabulary mastery. Vocabulary is the first factor affecting a text to be considered as difficuly. ${ }^{7}$ The other two factors are topic discussed and concepts. Realizing the existence of undeniable link between vocabulary mastery and reading comprehension, some researchers then decide to conduct researches about the two variables. Here are some of them:

\footnotetext{
${ }^{3}$ Christine Nuttall, Teaching Reading Skills in a Foreign Language, (London: Heinemann Educational Books, 1983). p. 18.

${ }^{4}$ Martha Dallmann, et. al., The Teaching of Reading, (Canada: CBS College Publishing, 1982). p. 159.

${ }^{5}$ John Charles Alderson, Assessing Reading, (Cambridge: Cambridge University Press, 2000) . p. 3.

${ }^{6}$ Martindale, "Improving Your Reading Comprehension", accessed from http://www.stateuniversity.com/blog/permalink/Reading-inCollege.html, on May 232011.

${ }^{7}$ Christine Nuttall, op.cit. p. 5.
} 
The first research by Arafa Efendi was much more intended to investigate how much vocabulary the students knew that could ensure them to understand a reading text. Besides, the sample was the first semester students of English major in the same institution where the researcher studied. It can be said that the students were the masters in English. ${ }^{8}$

The second research by Bambang Irfani used four variables - mastery of vocabulary, achievement motivation, perception on instructor's competence, and students' English reading comprehension. ${ }^{9}$ The third research by Mahardhika used three variables - students' interest in game activities, vocabulary mastery, and reading comprehension. The sample was the seventh grade students of SMP N 8 Surakarta. ${ }^{10}$

The last research by Rajini used four variables - vocabulary mastery, reading comprehension, style of studying, and studying achievement in Biology subject. The sample was the eleventh grade students of immersed class of SMA Negeri 4 Surakarta. The sample was selected by using purposive sampling. ${ }^{11}$

${ }^{8}$ Arafa Efendi, "The Correlation between Vocabulary Mastery and Reading Comprehension of S1 English Students of STBA LIA Yogyakarta in Academic Year 2010/2011", accessed from http://arafaefendi.blogspot.com/2011/01/correlation-between-vocabularymastery.html, on March 32012.

${ }^{9}$ Bambang Irfani, "A Correlational Study between the Mastery of Vocabulary, Achievement Motivation, and Perception on Instructor's Competence with Students' English Reading Comprehension at Lembaga Bahasa Inggris Bandar Lampung”, accessed from http://repository.unila.ac.id:8180/dspace/handle/123456789/912, on March 112012.

${ }^{10}$ Mahardhika, “A Correlational Study between the Students' Interest in Game Activities, Vocabulary Mastery, and Their Reading Comprehension of Seventh Grade Students of SMP N 8 Surakarta in Academic Year 2007/2008", accessed from http://digilib.uns.ac.id/pengguna.php?mn=showview\&id=5231 on March 11 2012.

${ }^{11}$ Rajini, "Studi Korelasi antara Vocabulary Mastery, Reading Comprehension dan Gaya Belajar dengan Hasil Belajar Biologi Siswa Kelas XI Imersi SMA Negeri 4 Surakarta Tahun Pelajaran 2010/2011”, accessed from http://digilib.fkip.uns.ac.id/contents/skripsi.php?id_skr=2055, on March 112012. 
This research is different from those previous researches. The sample was the first semester students of Economic Faculty of Alkhairaat University. They were ESP students, meaning they learned English to enrich their insight about their major economics. Therefore, reading comprehension here was positioned based on the need of the students. They need reading comprehension to enable them to understand economic literatures. The sample of this research was selected by using total sampling all the number of population was taken as the sample. There was no intention to find out how many vocabulary the students already mastered in order to understand an English reading text. This research was then conducted to answer several questions: (1) What is the level of correlation between variable $\mathrm{X}$ (vocabulary mastery) and variable Y (reading comprehension)?; (2) How significant is the contribution that can be given by variable $\mathrm{X}$ (vocabulary mastery) toward variable Y (reading comprehension)?; and (3) Is there positive correlation between variable X (vocabulary mastery) and variable $Y$ (reading comprehension)? To answer the questions, the researcher applied hypothesis testing which procedures explained further in research method.

The research objective is to find out the level of correlation between vocabulary mastery and reading comprehension, the significant contribution that could be given by vocabulary mastery toward reading comprehension, and the correlation between vocabulary mastery and reading comprehension.

The researcher only provided reading texts exclusively discussing about the students' major - economic management. The vocabulary mastery discussed in this research was limited on word meaning or literal meaning. This research focused on two levels of reading comprehension: factual level and interpretive or inferential level.

\section{Research Method}

The research used correlational research. Correlational research is procedures in quantitative research in which investigators measure degree of association (or relationship) between two or more variables using the statistical procedure of 
correlational analysis. ${ }^{12}$ There were two variables in this research: variable $\mathrm{X}$ standing for vocabulary mastery and variable $\mathrm{Y}$ standing as reading comprehension. All variables are equal since correlational study does not apply the terms such as dependent or independent variable. ${ }^{13} \mathrm{D}$ ue to the fact that the researcher needed to find out the correlation between vocabulary mastery and reading comprehension, the research design is then drawn as follows:

$\mathrm{X} \rightarrow \mathrm{Y} \quad 14$

In which: $\quad \mathrm{X}=$ vocabulary mastery

$\mathrm{Y}=$ reading comprehension

Population and sample are the subjects of research. The population and the sample of this research were 50 students of the first semester at Economic Faculty of Alkhairaat University. Since the researcher used total sampling, all the number of the population - 50 - was taken as the sample.

The researcher applied two kinds of instrument to help her collect data: non-test and tests. Non-test instrument refers to the closed questionnaire containing of ten numbers with five alternative choices, while tests refer to vocabulary mastery test and reading comprehension test with twenty multiple choice items respectively.

The following are the procedures of data collection that the researcher did: (1) Explaining about what the students had to do with the questionnaire; (2) D istributing the questionnaire to the students; (3) Giving fifteen minutes to the participants to fill the questionnaire; (4) Explaining about what the students had to do with the vocabulary mastery test; (5) Distributing vocabulary mastery test to the students; (6) Having the students answer the questions in the test for thirty minutes; (7) Explaining about what

12 John Creswell, Educational Research: Planning, Conducting, and Evaluating Quantitative and Qualitative Research, (Lincoln: University of Nebraska, 2005). p. 52.

${ }^{13}$ Muhammad Arif Tiro, Analisis Korelasi dan Regresi, (Makassar: State University of Makassar Press, 2008). p. 4.

${ }^{14}$ Riduwan, Belajar Mudah Penelitian untuk Guru - Karyawan dan Peneliti Pemula, (Bandung: Alfabeta, 2008). p. 222. 
the students had to do with the reading comprehension test; (8) D istributing reading comprehension test to the students; and (9) Having the students answer the questions in the test for thirty minutes.

The data gained from questionnaire were presented both quantitatively and qualitatively, while the data gained through tests were presented quantitatively. The following formula was used to analyze the data from questionnaire.

The number of students choosing the item

$\begin{array}{ll}\text { Score } & = \\ ------------------------------- & \mathrm{x} \\ 100 \% & \end{array}$

The total number of students

D ata analysis from tests contained of several steps as follows:

- Finding out the raw score of every student with the calculation 1 point for every correct item

- Finding out standard score of every student by using the following formula:

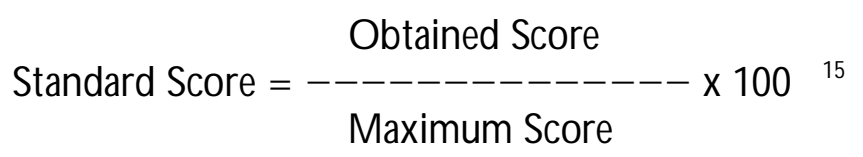

- Calculating the total of $\mathrm{X}$ and $\mathrm{Y}$ to get $\sum \mathrm{X}$ and $\sum \mathrm{Y}$

- Gaining the mean scores of $X$ and $Y$ which are symbolized as $\mathrm{MX}$ and MY by using these formulas.

$$
\begin{aligned}
& M X=\frac{\sum X}{n} \\
& M Y=\frac{\sum Y}{n}
\end{aligned}
$$

- Having the scores of $\mathrm{x}$ and $\mathrm{y}$ by using these formulas:

$$
\begin{aligned}
& \mathrm{x}=\mathrm{X}-\mathrm{MX} \\
& \mathrm{y}=\mathrm{Y}-\mathrm{MY}
\end{aligned}
$$

${ }^{15}$ Sutomo, Teknik Penelitian dan Pendidikan, (Surabaya: Bina Ilmu, 1985), p. 123.

${ }^{16}$ Suharsimi Arikunto, Prosedur Penelitian: Suatu Pendekatan Praktik, (Jakarta: Rineka Cipta, 2006), p. 313. 
- Having the score of $X^{2}$ and $Y^{2}$

- Having the score of $\sum \mathrm{X}^{2}$ and $\sum \mathrm{Y}^{2}$

- Multiplying $X$ and $Y$ scores to get $X Y$ score.

- G etting the total score of XY ( $\Sigma X Y)$

- Having the value of $\mathrm{r}$-counted by applying this following formula:

$$
r x y=\frac{n\left(\sum X Y\right)-\left(\sum X\right) \cdot\left(\sum Y\right)}{\sqrt{\left\{n \cdot \sum X^{2}-\left(\sum X\right)^{2}\right\} \cdot\left\{n \cdot \sum Y^{2}-\left(\sum Y\right)^{2}\right\}}}
$$

- In order to answer the first research question, the value of $r$ counted became the measurement to determine the level of correlation between variable $\mathrm{X}$ and variable $\mathrm{Y}$ by applying the following table proposed by Riduwan. ${ }^{18}$

\section{Table 2}

Interpretation of Coefficient Comelation of r-Value

Interval Comelation

$$
\begin{aligned}
& 0.80-1.000 \\
& 0.60-0.799 \\
& 0.40-0.599 \\
& 0.20-0.399 \\
& 0.00-0.199
\end{aligned}
$$

\section{Level of Correlation}

very strong

strong

strong enough

weak

very weak

- To answer the second research question about the significant contribution that can be given by variable $\mathrm{X}$ toward variable $\mathrm{Y}$, the following formula of Coefficient $D$ eterminer was used:

$$
\mathrm{CD}=\mathrm{r}^{2} \times 100 \%
$$

- In order to answer the last research question, the value of $r$ counted should be compared to the value of $r$-table.

In testing hypothesis, $r$-table was used to make a comparison to the result of $r$-counted. If the r-counted is same as or higher than the r-table, the alternative hypothesis $(\mathrm{Ha})$ is accepted and the null hypothesis (Ho) is rejected, meaning there is positive correlation between vocabulary mastery and reading comprehension. Conversely, if the r-table is higher than the $r$ counted, the null hypothesis (Ho) is accepted and the alternative

\footnotetext{
${ }^{17}$ Riduwan, op.cit. p. 138.

${ }^{18}$ Ibid., p. 138.

${ }^{19}$ Riduwan, op.cit. p. 139.
} 
hypothesis $(\mathrm{Ha})$ is rejected, meaning there is negative correlation between vocabulary mastery and reading comprehension.

\section{Result and Discussion}

The questionnaire was analyzed by calculating how many subjects choosing a certain item. After that, by applying the following formula, the researcher then got the percentage of every item.

$$
\text { Percentage }=\frac{\text { The number of subjects choosing the item }}{\text { The total number of subjects }} \times 100 \%
$$

The dominant number of percentage became the underlining base to take conclusion that $76 \%$ of the students agreeing that English is an interesting subject, 52\% of them strongly agreeing that they need to study English, 48\% of them agreeing and the other $48 \%$ even strongly agreeing that learning English vocabulary is important, $70 \%$ of them agreeing that learning vocabulary through reading passages is an exciting activity, $54 \%$ of them agreeing that memorizing vocabulary is such a pleasing activity to do, $54 \%$ of them agreeing that reading should be the first activity done in every meeting of English class, 58\% of them strongly agreeing that being able to read English texts enables them to expand their insight about economics, $66 \%$ of them agreeing that reading English texts is an exciting activity, $46 \%$ of them agreeing that the more vocabulary they have, the more able they are in reading English texts, and $50 \%$ of them agreeing that the lists of vocabulary existing after reading texts really work in guiding them to comprehend English texts.

In finding out the result of tests, first of all, the researcher totalized every correct item gained by each student for both vocabulary mastery test and reading comprehension test. The students got 1 score for every correct item. Since there were twenty items in every test, the students would get 20 points as their raw score if they could answer all the questions correctly.

The standard score of every student was got by using the formula proposed by Sutomo ${ }^{20}$ as presented in the discussion about research method. The total number of both

${ }^{20}$ Sutomo, loc.cit. 
vocabulary mastery test and reading comprehension test was 20 respectively. Since every correct item equals 1 point, the maximum score is 20 .

The next step was finding out the r counted - the value of rxy. In order to apply the formula of rxy as written in the previous discussion about research method, the value of $X 2, Y 2$ and $X Y$ should be gained before. To get the value of $\mathrm{x}$ and $\mathrm{y}$ above, the value of MX and MY should be found before. MX standing for mean score of variable $X$ was got by dividing the total score of variable $X\left(\sum X\right)$ and the total number of the students $(n=50)$. While MY which refers to mean score of variable $Y$ was gained by dividing the total score of variable $\mathrm{Y}\left(\sum \mathrm{Y}\right)$ and the total number of the students. Here is the result:

$$
\begin{aligned}
& \mathrm{MX}=\frac{\sum \mathrm{X}}{\mathrm{n}}=\frac{2875}{50}=57.5 \\
& \mathrm{MY}=\frac{\sum \mathrm{Y}}{\mathrm{n}}=\frac{3045}{50}=60.9
\end{aligned}
$$

Having found the value of MX and MY, the value of $\mathrm{x}$ and $\mathrm{y}$ were then calculated by using the formula written in the discussion of research method.

After all the calculation was completed, the next step was gaining the value of r-counted as follows:

$$
\begin{aligned}
r x y & =\frac{n\left(\sum X Y\right)-\left(\sum X\right) \cdot\left(\sum Y\right)}{\sqrt{\left\{n \cdot \sum X^{2}-\left(\sum X\right)^{2}\right\} \cdot\left\{n \cdot \sum Y^{2}-\left(\sum Y\right)^{2}\right\}}} \\
& =\frac{50(182875)-(2875) \cdot(3045)}{\sqrt{\left\{50.177325-(2875)^{2}\right\} \cdot\left\{50 \cdot 194975-(3045)^{2}\right\}}} \\
& =\frac{389375}{\sqrt{600625.476725}} \\
& =\frac{389375}{\sqrt{286332953125}} \\
& =\frac{389375}{535100.88} \quad=0.727
\end{aligned}
$$


Through the calculation, it was found that the value of $\mathrm{r}$ counted was 0.727. By applying the table of Interpretation of Coefficient Correlation of $\mathrm{r}$-Value as presented in the research method, the value 0.727 was located between 0.60 and 0.799 . It means the level of correlation between vocabulary mastery and reading comprehension was strong.

The next step was finding out the value of CD (Coefficient D eterminer) which refers to significant contribution given by vocabulary mastery toward reading comprehension as follows:

$$
\begin{aligned}
\mathrm{CD} & =\mathrm{r} 2 \times 100 \% \\
& =0.727^{2} \times 100 \% \\
& =0.528 \times 100 \% \\
& =52.8 \%
\end{aligned}
$$

From the calculation, it was found out that the significant contribution that can be given by vocabulary mastery toward reading comprehension was as much as $52.8 \%$. It means vocabulary mastery gave much contribution to reading comprehension.

Hypothesis testing was done by comparing the value of $r$ counted and the value of r-table using $5 \%$ level of significant. Since the value of $r$-counted 0.727 was higher than the value of $r$ table 0.279 , the alternative hypothesis ( $\mathrm{Ha}$ ) was accepted while the null hypothesis (Ho) was rejected. It means there was positive comelation between vocabulary mastery and reading comprehension.

In order to strengthen the result of hypothesis testing, the researcher used significance testing by comparing the value of $t$ counted and t-table. If the value of t-counted is higher than the value of $t$-table, then there is significant correlation between vocabulary mastery and reading comprehension. Conversely, if the value of $t$-table is higher than the value of $t$-counted, then there is no significant correlation between both of the variables. The value of t-counted was gained through calculation by the following formula suggested by Riduwan. ${ }^{21}$

$t-$ counted $=\frac{r \sqrt{n-2}}{\sqrt{1-r^{2}}}$ and the result is 7.330

\footnotetext{
${ }^{21}$ Riduwan, op.cit. p. 139.
} 
By using 0.05 level of significant $(\alpha)$, and 48 degree of freedom $(\mathrm{df}=\mathrm{n}-2=50-2=48)$, the value of $\mathrm{t}$-table then could not be found in the table. Therefore, the only way to gain the value of t-table was to apply interpolation computation by involving the closest degree of freedom available in the table - 40 and $60 \mathrm{df}$. The interpolation computation to get the value of t-table can be seen as follows.

Interpolation computation formula $=\frac{\mathrm{a}}{\mathrm{b}} \times \mathrm{c}$

In which

$\mathrm{a}=$ degree of freedom minus the closest degree of freedom found in the $r$ - table which is lower than the exact degree of freedom being searched

$\mathrm{b}=$ the closest degree of freedom found in the r-table which is higher than the exact degree of freedom being searched minus the closest degree of freedom found in the r-table which is lower than the exact degree of freedom being searched

$\mathrm{c}=$ the value of degree of freedom which is lower than the exact degree of freedom minus the value of degree of freedom which is higher than the exact degree of freedom by using 0.05 level of significance

So, the calculation should be as follows.

$$
\begin{aligned}
\mathrm{a} & =48-40 \\
& =8 \\
\mathrm{~b} & =60-40 \\
& =20 \\
& 40 \rightarrow 1.684 \\
& 60 \rightarrow 1.671 \\
\mathrm{C} & =1.684-1.671 \\
& =0.031
\end{aligned}
$$

$\begin{aligned} \text { Interpolation } & =\frac{\mathrm{a}}{\mathrm{b}} \times \mathrm{c} \\ & =\frac{8}{20} \times 0.013=0.0052\end{aligned}$ 
The value of $\mathrm{t}$-table $=1.684-0.0052$

$$
=1.6778
$$

Since the value of $\mathrm{t}$-counted (7.330) was higher than the value of t-table (1.6778), then the significance was positive, meaning there was significant correlation between variable $\mathrm{X}$ (vocabulary mastery) and variable $\mathrm{Y}$ (reading comprehension). Therefore, it is clear that there was significant comelation between vocabulary mastery and reading comprehension.

A part from the fact that vocabulary mastery and reading comprehension had positive correlation, the researcher would also like to comment something related to the result of each test. The mean score of reading comprehension test (60.9) was higher than the mean score of vocabulary mastery test (57.5), while in fact, the vocabulary becoming the questions in vocabulary mastery test was taken from the two reading texts used in reading comprehension test. It means the students found it easier to complete the reading comprehension test rather than the vocabulary mastery test. The researcher believes that the main cause is the context. The context in this research refers to the reading texts submitted as part of the reading comprehension test. Most of the questions in vocabulary mastery test did not include context. Responding to this finding, the researcher concludes that vocabulary should be better taught in context rather than separated from context.

\section{Conclusion}

Having found the result the research through both questionnaire and tests, the researcher then draws conclusion that: (1) The level of correlation between vocabulary mastery and reading comprehension was strong; (2) The significant contribution that could be given by vocabulary mastery toward reading comprehension was as much as $52.8 \%$, meaning variable $\mathrm{X}$ (vocabulary mastery) gave much contribution to variable $\mathrm{Y}$ (reading comprehension); (3) There was positive correlation between variable $\mathrm{X}$ (vocabulary mastery) and variable $\mathrm{Y}$ (reading comprehension). In other words, the more vocabulary the students have, the better their reading comprehension is; and (4) Through questionnaire, there were $46 \%$ of the respondents from 50 students of the first semester of Economic Faculty of Alkhairaat 
University agreed that vocabulary really takes a role in enabling them in comprehending English texts. In other words, the more vocabulary they have, the better they are in comprehending English texts.

Based on the result of the research, the researcher underlines several points that are expected to improve both vocabulary mastery and reading comprehension of the first semester students of Economic Faculty of Alkhairaat University. Library is the core of a university. Therefore, it should provide more references written in English related to economics, especially English D ictionary for economics and reading materials related to economics. Besides the printed sources - books, unprinted materials - those taken from internet - are also useful to broaden the students' knowledge about economics. By reading a lot, students are encouraged to learn vocabulary in context. However, English I subject should cover the material related to general English first since the students need Basic English in English I before they get English for E conomics in English II. 


\section{REFERENCES}

Alderson, J. C. (2000). Assessing Reading Cambridge: Cambridge University Press.

Arikunto, S. (2006). Prosedur Penditian: Suatu Pendkkatan Praktik. Jakarta: Rineka Cipta.

Creswell, J. W. (2005). Educational Rescerch Planning Conduting and Evaluating Quantitative and Qualitative Research Lincoln: University of Nebraska.

D allmann, M., Roger L. R. and John J. D . (1982). The Teading of Reading Canada: CBS College Publishing.

Efendi, A. (2011). The Condation between Vocabulary Mastery and Reading Comprehension of S1 Engish Students of STBA LIA Yogjakarta in Acadamic Yer 2010/2011. Via <http:/ / arafaefendi.blogspot.com/ 2011/ 01/ correlationbetween-vocabulary-mastery.html $>$ [11/ 03/ 12]

Irfani, B. (2006). A Condational Study between the Mastery of Vocabulary, Adievement Mativation, and Peception on Instructor's Competence with Students Engish Reading Comprenension at Lenbaga Bahasa Ingyis Bandar Lampung Via <http:/ / repository.unila.ac.id:8180/ dspace/ handle/ 12345678 9/912> [11/ 03/ 12]

Mahardhika. (NY). A Comdational Study beween theStudants Interet in Game Adivities, Vocabulary Mastery, and Ther Reading Comprehension of Seventh GradeStudents of SMP N 8 Surakarta in Acadamic Yer 2007/2008. Via $<$ http:/ / digilib.uns.ac.id/ pengguna.php?mn=showview\&id=5 231> [11/ 03/ 12]

Martindale, G. (2007). Improving Yar Reading Comprehension Via <http:/ / www.stateuniversity.com/ blog/ permalink/ Readingin-College.html> [23/ 05/ 11]

Nuttall, C. (1983). Teading Reading Skills in a Foreign Language London: Heinemann Educational Books. 
Rajini. (2011). Studi Kordasi antara Vocabulary Mastery, Reading Comprehension dan Gaya Bdajar dengan Hasil Bdajar Bidogi Siswa Kdas XI Imesi SMA Negi 4 Surakarta Tahun Pdajaran 2010/ 2011. Via $<$ http:/ / digilib.fkip.uns.ac.id/ contents/ skripsi.php?id_skr=2 055> [11/ 03/ 12]

Read, J. (2000). Assessing V cabalary. Cambridge: Cambridge University Press.

Riduwan. (2008). Bdajar Mudah Penditian untuk Gunu - Karyawan dan Penditi Pemila Bandung: Alfabeta.

Sutomo. (1985). Teknik Penditian dan Pendidkan Surabaya: Bina Ilmu.

Thornbury, S. (2002). HowtoTeach V oabulary. Edinburgh: Pearson Education Limited.

Tiro, M. A. (2008). Analisis Kardasi dan Regei. Makassar: State University of Makassar Press. 